\title{
Focus
}

\section{Hoe kun je nu over Hem horen als Hij niet verkondigd wordt?}

\author{
C.J. de Ruijter
}

Bert de Leede/Ciska Stark, Ontvouwen. Protestantse prediking in de praktijk (Zoetermeer: Boekencentrum 2017), 304 p., € 34,90 (ISBN 978 $9023970132)$.

Gerrit Immink, Over God gesproken. De preek in theorie en praktijk. (Utrecht: Boekencentrum 2018), 298 p., €21,99 (ISBN 978902395233 6).

's Zondags gaan we naar de kerk. En hoe de dienst ook verder vorm krijgt, daar horen we in ieder geval een preek. Sta je daar eens een keer bij stil, dan kun je onder de indruk raken van de genadige structuur die een christenleven daarmee krijgt. Er schijnt licht op je pad. En daar heeft die preek echt een plek in.

Maar als het je wekelijkse taak is om te preken ken je daar ook de andere kant van. Wat een worsteling met de tekst, de tijd en je agenda kan die preek voor zondag opleveren. En dan hebben we het nog niet eens over de afstand die je steeds weer overbruggen moet tussen die oude vertrouwde teksten en de hectische wereld van vandaag. De preek mag dan al eeuwenlang een baken zijn in het christelijk leven, zonder problemen is de zondagse kerkdienst niet. En de preek deelt natuurlijk in die crisis. De vanzelfsprekendheid waarmee vroegere generaties 's zondags naar de kerk gingen is allang verdwenen. En de kritische inbreng van de hoorders van vandaag kan gemakkelijk voor spanning zorgen rond je kerntaak als voorganger.

Als predikers kunnen we op dit punt dan ook wel een steun in de rug gebruiken. Met veel plezier vestig ik dan ook de aandacht op twee homiletische studies die de preek opnieuw met veel elan op de kaart zetten. Vorig jaar al kwam het prachtig uitgegeven homiletisch leerboek van Bert de Leede en Ciska Stark uit: Ontvouwen. Protestantse prediking in de praktijk. En zeer onlangs verscheen van de hand van Gerrit Immink een stevige studie rond de preek: Over God gesproken. De preek in theorie en praktijk. Als preken tot je opdracht hoort, loont het bijzonder de moeite om eens een poosje met deze gidsen op te trekken in het nooit compleet ontgonnen en in kaart gebrachte veld van de prediking. 


\section{Stimulerend studieboek}

Eerst maar aandacht voor het boek van De Leede en Stark. Het ligt al zo'n anderhalf jaar in de winkel en in vele studeerkamers. Ik denk ook dat niet veel predikers het in die tijd over het hoofd gezien zullen hebben. Het mag dan ook gezien worden, want wat is dit een prachtige uitgave met liefde voor belettering, omslag en band. Hier krijg je echt een BOEK in handen.

En wat voor de uiterlijke verschijningsvorm geldt moet je zeker ook zeggen over de inhoud. De auteurs presenteren het als een leerboek. Dat is het ook, maar ook als naslagwerk is het niet te versmaden. Een uitvoerige inhoudsopgave helpt je de weg te vinden (helaas ontbreekt een register).

Die weg wordt op een heel originele manier uitgestippeld. Na een eerste hoofdstuk waarin de theologische plek van de preek in de eredienst wordt verkend, volgen vijf hoofdstukken die de fasen van het preekproces beschrijven onder de categorieën oriënteren, inzoomen, verwoorden, uitspreken en delen. Vanaf het moment dat je met de preek begint (ja wanneer is dat moment eigenlijk?) tot en met de verwerking door de hoorders wordt het proces zorgvuldig beschreven.

Alleen in de aanpak al merk je hoe ervaren de auteurs zijn zowel in het preken zelf als in het preekonderwijs. Het originele van die aanpak zit wat mij betreft vooral in de dimensies die de structuur van de behandeling vormen. Elk hoofdstuk start met het perspectief van de cultuur (in welke context zijn we bezig), vervolgens dat van de theologie (welke plaats en betekenis heeft de Schrift in dit verband), de spiritualiteit (uit welke bronnen leeft en werkt de voorganger) en de praktijk (hoe ga je concreet te werk). Een bijzondere vondst is dat bij dat laatste onderdeel de elementen cultuur, theologie en spiritualiteit opnieuw met zoveel woorden ter sprake komen. Soms geeft dat een beetje een Droste-effect, maar terecht is het wel, dat je juist in de praktijk van het preekproces methodisch rekenschap van die elementen geeft.

De auteurs geven daarmee overigens wel een heel eigen invulling aan de homiletische drieslag. Het hoordersperspectief benoemen zij als de culturele dimensie, het perspectief van de Schrift komt in de theologische oriëntatie aan bod en de spirituele invalshoek vertegenwoordigt het perspectief van de prediker. Aan de ene kant is het jammer dat de strikte hantering van de drieslag zo wat op de achtergrond raakt. Ordelijke preekvoorbereiding heeft daar veel bij te winnen. Aan de andere kant valt er ook wel wat te zeggen voor die uitbreiding van de drieslag, zeker omdat op deze manier een wat bredere reflectie rond het preekproces gestimuleerd wordt.

Al lezend kreeg ik veel zin om nog eens een curriculum lang aan de slag te gaan met dit bijzonder stimulerende studieboek. Als student krijg je hier goud in handen. 


\section{Een cyclisch proces}

In het totaalbeeld dat de auteurs in hun boek oproepen komt mooi uit hoe in de prediking sprake is van een consequent cyclisch proces. Natuurlijk verloopt het preekproces vanaf een startpunt dat de prediker ergens op weg naar de zondag kiest en het eindigt in het gemeentegesprek als follow-up na de dienst. Maar dat lineaire element wordt door een principieel circulair element gecompleteerd. Mijn preek voor aanstaande zondag begint niet bij het nulpunt van mijn opgeruimde bureau op maandagmorgen. Er is al veel langer een permanent proces gaande van luisteren naar de Schrift, waarnemen wat er gebeurt in de leefwereld van de hoorders en oefening in de persoonlijke omgang met God. Ook als ik bijvoorbeeld nadenk over mijn woordkeus voor zondag is dat opgenomen in een veel langer lopend proces van oefening, corrigeren, leren en ontdekken.

Op dit spoor noemen de auteurs de optie dat je in feite bij elk hoofdstuk afzonderlijk kunt inzetten. Dat lijkt me met name voor predikers die al regelmatig voorgaan een bijzonder leerzame aanwijzing. Voer gewoon maar eens een punctie uit in de geleding van je preekpraktijk en laat je door De Leede en Stark bij de hand nemen om vanuit de verschillende perspectieven eens grondig na te denken over een apart aspect van je preekwerk.

Het boeiende van de aanpak in dit boek is wel dat theologie en methode constant samen optrekken. De behandeling van de verschillende fasen gaat nooit op in een kaal methodische procesbeschrijving. Altijd weer word je in de aandacht voor het ambachtelijke werk teruggeroepen naar het eeuwenoude theologische discours. Ik heb bij het doorwerken van het boek dat element als erg stimulerend ervaren. Daar zit ook wel een nadeel aan. Het preekambacht vindt natuurlijk plaats binnen de vierkante meter van je preekvoorbereiding voor aanstaande zondag. Dat vind je hier ook concreet terug. En dan is er uiteraard niet veel ruimte om recht te doen aan de vele relevante verwijzingen. (Bijvoorbeeld: bij de behandeling van het bijbels-theologisch kader waarbinnen je de preek voorbereidt krijgt Rein Bos slechts een enkele zin toebedeeld in zijn spreken over de sleutelbos, terwijl die metafoor een hoofdstuk verderop weer opduikt in een pittige praktijkopdracht.) Maar voor mij overheerst toch het grote voordeel van de gekozen aanpak. Die creëert namelijk een rijke leeromgeving in het studieproces.

\section{Theologische homiletiek in hoofdlijnen}

Het boek van Immink is in een heel andere toonsoort gecomponeerd. Bij hem staat niet het ambacht van de prediker centraal maar meer de grote lijnen die door de eeuwen heen getrokken zijn in de theologie van de preek. Ook hier is de toegankelijkheid van het boek gegeven met de uitvoerige inhoudsopgave 
(het beknopte zaakregister helpt je niet echt verder). Achtereenvolgens bespreekt Immink de preek als Woord van God (de centrale overtuiging van de protestantse theologie), de preek als performance (het gebeuren zoals we dat 's zondags meemaken), de preek als vertolking van de Bijbel (met veel aandacht voor nieuwere hermeneutische vragen) en de preek als blijde boodschap (een korte materiële homiletiek rond de boodschap van de grote feesten van de kerk).

Op deze manier ontstaat een brede oriëntatie in het homiletisch discours sinds de zestiende eeuw. Al lezend krijg je de essentie van de grote discussies rond de prediking mee. Overigens voelt Immink zich lang niet altijd geroepen om zelf een positie in dat geheel in te nemen. Eerder is hij de gespreksleider die de diverse stemmen in het homiletisch koor hoorbaar maakt en zo tot hun recht wil laten komen. Dat betekent trouwens niet dat je als lezer in een louter theoretisch verhaal belandt. Immink besteedt er veel aandacht aan om zijn betoog te illustreren met preekfragmenten. Dat geeft vooral zijn historische overzicht kleur. Op mij had het als effect dat ik me hier bij het lezen vaak kerkganger voelde, terwijl ik me bij De Leede en Stark vooral aangesproken voelde als voorganger op weg naar zondag.

Als je twee boeken over de preek naast elkaar leest roept dat automatisch de vraag naar de vergelijking op. Toch denk ik dat je in dit geval geen van beide daarmee recht zou doen. Zoals ik al aangaf zijn de inslag en bedoeling van de auteurs heel divers. Eerder zou je kunnen zeggen dat ze elkaar aanvullen. Waar het ambacht van het preekproces alle aandacht krijgt bij De Leede en Stark en de inhoudelijke homiletiek wat minder ter sprake komt, gebruikt Immink zo veel mogelijk ruimte om de eeuwenlange theologische bezinning rond de preek in kaart te brengen, waardoor de concrete methodiek in het homiletisch handwerk meer naar de achtergrond schuift.

\section{Gods werk en mensenwerk}

Elke prediker kent het spanningsveld dat in heel het preekproces voelbaar wordt. Het gaat om het Woord van God dat klinken zal. Maar al prekend moet je wel je eigen woorden gebruiken en dan vooral ook woorden die de hoorder kan ontvangen en meenemen. Sinds de dialectische theologie dat spanningsveld thematiseerde keert het terug in allerlei homiletische discussies. En de nieuwere hermeneutische vragen hebben het alleen maar spannender gemaakt. De stoere visie dat de prediking van Gods Woord zelf ook Gods Woord genoemd mag worden (Bullinger) is daardoor binnen de protestantse traditie behoorlijk onder druk komen te staan. En veel van de vraagtekens die intussen in dat kader gezet zijn moeten ons ook tot bescheidenheid brengen. Die visie kan in ieder geval geen claim vooraf richting de hoorders zijn. 
Tegen die achtergrond valt het goed te begrijpen dat beide boeken heel terughoudend zijn over de verhouding tussen de preek van zondag en het eigen Woord van God. Wat mij betreft had dat wat royaler gekund.

Dat treft me nog het meest bij Immink. Alleen al de typering dat in de preek over God gesproken wordt lijkt de preek behoorlijk bij het spreken van God zelf vandaan te trekken. Wel is er op dit punt bij Immink een duidelijke kanteling waarneembaar. In zijn laatste hoofdstuk laat hij eigenlijk alle terughoudendheid varen. Als het gaat over de grote heilsfeiten die verkondigd worden op de feesten van de kerk gaat hij als het ware helemaal los. Hier ontmoet je de prediker die geraakt is door de wonderlijke boodschap die hij te brengen heeft. En het is alsof hij ons als predikers wil toeroepen: denk eraan, je hebt echt iets te vertellen als je de kansel opgaat! Hartverwarmend.

De Leede en Stark zijn wat minder terughoudend op het genoemde punt. Met zoveel woorden benoemen ze in één adem werk van God en mensenwerk rond de preek. En ook in hun uiteindelijke definitie formuleren zij dat 'de prediking staat onder de belofte van de Geest dat waar het Woord in geloof ontvangen en gedeeld wordt, het leven van mens en samenleving zich opent en ontvouwt naar Gods toekomst'. Maar tegelijkertijd valt op dat het Woord van God hier nogal naar de kant van het horende subject getrokken wordt. Het is alsof de preek eerst een nieuw startpunt creëren moet waarin het Woord kan gaan klinken. In plaats van nieuw zou ik liever zeggen opnieuw. $\mathrm{Er}$ is immers om de prediker heen een gemeente die het Woord ontvangen heeft. Zonder haar zou geen prediker zich geroepen voelen om een preek te maken. Misschien zou hier wat meer gerichte aandacht passen voor het gebed rond het hele preekproces.

\section{Een biddende en prekende gemeenschap}

Bij ons thuis bad mijn vader 's zondagsmorgens aan tafel voor de kerkdienst 'dat Uw dienaar Uw Woord moge brengen naar de mening van Uwen Geest en dat het voorspoedig moge zijn in hetgeen waartoe Gij het zendt'. Daar heb ik geleerd biddend naar de kerk te gaan. Later vond ik de woorden terug in Jesaja 55, een tekst die De Leede en Stark terecht ook op een belangrijk punt in hun boek noemen. Het bijzonder mooie laatste hoofdstuk van Ontvouwen schetst zo een gemeenschap waarin het gebrachte Woord gedeeld wordt en de beloofde voorspoed ook echt voelbaar wordt.

Je zou daar natuurlijk ook mee kunnen beginnen. Er is namelijk niet alleen een follow-up nadat er gepreekt is. Er is al een biddende gemeenschap voordat de prediker aan zijn werk voor aanstaande zondag begint.

Ik vraag daar speciaal aandacht voor. De Leede en Stark leggen namelijk veel nadruk op de hoorder als het gaat om de verhouding tussen mensen- 
woord en Woord Gods. Voor Immink geldt hetzelfde. Dat is wel begrijpelijk als reactie op de massieve preekvisie die de preek bij voorbaat identificeerde met Gods eigen Woord. Maar zo'n reactie leidt er gemakkelijk toe dat prediker en hoorders in het preekproces tegenover elkaar geplaatst worden. Dat kan alleen maar tot verdere vervreemding leiden rond het horen naar het Woord. Daarom is het belangrijk om beiden, prediker en hoorders, bij voorbaat als deelgenoten te zien in de biddende en horende gemeenschap.

Juist die biddende gemeente is het sprekende teken dat God hier allang bezig is. Het is zijn Woord dat de gemeenschap sticht. Aan die gemeente vertrouwt Hij zijn Woord toe. En uit die rijen mag er dan één naar voren komen om te preken. Daarmee is die biddende gemeenschap ook een prekende gemeenschap. En omgekeerd: laat die prediker ook in zijn voorbereidingsproces een biddend lid van de gemeenschap zijn. Biddend om de Geest die het Woord ontsluit, biddend om zelf te willen en kunnen luisteren, biddend voor de hoorders om hen al prekend werkelijk lief te hebben.

Op die manier wordt onnodige spanning tussen prediker en hoorder voorkomen en overbrugd. De homiletische drieslag is immers gesitueerd binnen het werkveld van de Heilige Geest.

\section{De preek in haar element}

Apart vraag ik ten slotte aandacht voor een element dat in beide boeken methodisch een rol speelt. De auteurs gebruiken behoorlijk wat preekfragmenten in de gang van hun betoog. Dat verheldert vaak het punt dat aan de orde is. De Leede en Stark maken er vooral gebruik van als illustratie van een methodisch aandachtspunt waar ze een oefening bij formuleren. Doorgaans is dat zeer to the point. Bij Immink heeft het een veel bredere functie, omdat hij de theologische preekvisie tastbaar maken wil aan de hand van de concrete preek. Daardoor ontstaat een levendige verbinding tussen theorie en praktijk.

Tegelijkertijd wordt juist zo voelbaar hoe moeilijk de preekpraktijk te vangen is in woorden op papier. Preken doen we in de bedding van de eredienst waar de gemeente vergaderd is voor het aangezicht van God. Daar is de preek in haar element, waar we biddend, belijdend en offerend samen zijn in Gods naam. Immink spreekt met voorliefde over de performance van de preek. Die is daar gesitueerd! Ik denk dat we die liturgische bedding moeilijk kunnen overschatten. Daar waar we samen de harten verheffen tot God (Noordmans noemde dat het kernmoment van de gereformeerde liturgie) kan de preek haar performatieve kracht van Godswege ontvangen. Daarom is een uitgeschreven preek ook een geamputeerde preek, losgemaakt uit de context waarin ze op haar plaats valt als een woord gesproken op zijn tijd. En zeker een preekfragment wordt dan gemakkelijk tot een moot vis die sterk vervreemd is 
van dat soepele dier dat zich in het water zo prachtig beweegt en in zijn element is.

Bij zo'n fragment wordt je verlangen wakker naar die bezielende ruimte waarin de boodschap van het geloof verkondigd wordt.

De auteurs van beide boeken hebben ons een grote dienst bewezen in de stimulans die ze ons bieden om daar onze krachten aan te geven. De Leede en Stark hebben met hun boek de actuele vragen rond de preek duidelijk in kaart gebracht en bieden een bijzonder bruikbaar kader om ze serieus te nemen in de wekelijkse preekvoorbereiding. Immink zet die vragen in historisch perspectief en steekt je als prediker vooral theologisch-inhoudelijk een hart onder de riem: je hebt een boodschap die ertoe doet.

Met dat al zijn de problemen rond de preek niet voorbij, zeker niet. De worsteling zal ons wel bekend blijven. Maar die mag staan in het teken van de belofte die alles overstijgt. 